\title{
Penanaman Pendidikan Antikorupsi pada Anak Usia Dini melalui Metode Bercerita
}

\author{
Muti'ah $^{1}$, Anita Trisiana ${ }^{2}$, Agus Setiawan $^{3}$, Lasmini $^{4}$ \\ ${ }^{1234}$ Universitas Slamet Riyadi \\ * e-mail: muti.win@gmail.com
}

\begin{abstract}
Corruption cases in Indonesia increase every year, how much loss to the state as a result of corruption. Corruption is a big threat to a country because it can harm the country and make people miserable. To tackle increasingly widespread corruption, it is necessary to have character education from an early age, one of which is to include it in the curriculum for early childhood, because the development period of early childhood as the golden age of children is the foundation of morals and character when one grows up to become an adult. Corruption by telling stories or storytelling is considered very appropriate because children do not feel taught but by telling stories they can insert moral values, morality without the impression of being coercive and pressing. With the storytelling method, it will be easy to instill character values such as being honest, not greedy and greedy in children, so that children will be able to apply them in the habituation of daily life since they were small. Parents, teachers and the surrounding environment are very important supporting factors in the formation of this anti-corruption character, so good cooperation is needed between them.
\end{abstract}

Keywords: Anticorruption; early childhood; story telling

How to cite : Muti, M. (2021). Indonesia Penanaman Pendidikan Antikorupsi pada Anak Usia Dini Melalui Metode Bercerita. Pedagogi: Jurnal Ilmu Pendidikan, 21(2), 121-127. https://doi.org/https://doi.org/10.24036/pedagogi.v21i2.1145

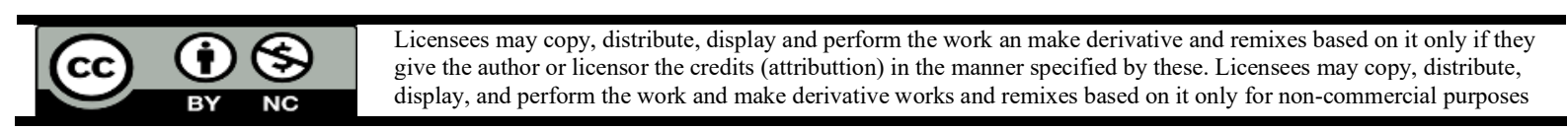

\section{PENDAHULUAN}

Dimasa keemasannya yaitu usia antara 0-5 tahun anak akan tumbuh dan berkembang secara pesat dan sangat peka terhadap lingkungan sekitarnya. Dimasa tersebut adalah tahap awal mereka untuk belajar karena mudah terstimulasi dan pekaterhadap aspek-aspek yang mereka lihat, dengar dan rasakan dilingkungannya.

Anak-anak tumbuh dan berkembang dalam periode emas ini akan melewati tahapan berupa daya minat dan ingin tahu yang sangat tinggi terhadap sesuatu hal dan aspek-aspek tertentu pada lingkungannya. Dengan belajar sambil bermain maka anak akan mampu mengembangkan kemampuan minat bakatnya, pembentukan karakter yang kuat dan daya pikir yang intelektual. Belajar akan memberikan perubahan perilaku terhadap individu dari pengalaman- pengalaman yang diperolehnya baik secara internal pribadi maupun dari interaksi dengan lingkungannya. Sedangkan belajar adalah tindakan yang dilakukan secara sengaja dan dilakukan secara bertahap untuk mencapai tujuan yang diharapkan.

Dengan belajar akan membentuk karakter-karakter baik pada individu (Rusman, 2015). Belajar menjadi faktor penting dalam pembentukan karakter dan perilaku seperti kejujuran, kedisiplinan, kasih sayang, menghormati, menghargai dan sebagainya. Terbentuknya karakter individu sangat dipengaruhi oleh cara belajarnya, kegiatan belajar yang baik dapat terlaksana 
dengan adanya pendidikan yang berkarakter didukung oleh elemen-elemen dalam pendidikan Anak Usia Dini.

Pembelajaran bisa berfungsi untuk menumpas korupsi secara berlahan-lahan lewat perantara modul pendidikan secara kontekstual dengan pesan- pesan yang mau di informasikan berkenaan dengan korupsi. Penanaman nilai pembelajaran kepribadian sangatlah berarti di terapkan pada anak umur dini. Dalam pembelajaran kepribadian bagi (Makruf, 2012) ada 9 pilar yang saling berhubungan, tanggungjawab, saling menghormati, bersikap adil, sikap pemberani, sikap jujur, kewarganegaraan, kedisiplinan, serta intensitas. Pendidikan karakter sangat penting untuk diimplementasikan sejak dini pada anak mulai dari rumah, lembaga formal, di dalam interaksi kehidupan bermasyarakat dan dunia usaha. Menurut (Makruf, 2012) tindakan anti korupsi dapat diimplementasikan dari kegiatan-kegiatan dirumah maupun di sekolah. Melalui pendidikan nasional akan mampu mengembangkan nilai sembilan pilar karakter tersebut. Terdapat beberapa pilar tertentu yang harus ditekankan, sesuai dengan permasalahan bangsa yang dihadapi. Contohnya ditemuinya banyak permasalahan korupsi yang terjalin di negeri kita dengan ditemui kenyataan terdapatnya ketidakadilan, maka kepribadian kejujuran sangat berarti buat ditanamkan semenjak dini.

Pembelajaran anak umur dini ialah pembelajaran tingkatan dasar peletakan perilaku serta pembuatan kepribadian. Dengan demikiam buat pembelajaran anak umur dini pula butuh diciptakan, sehingga buat menanamkan kepribadian bisa masuk secara baik kepada anak. Kejujuran jadi pondasi dari rasa yakin diri. Perilaku serta rasa yakin (trust) butuh ditanamkan pada kanak- kanak semenjak dini dalam pengasuhan mereka. Perlu adanya teladan dari orang tua dan keluarga sebagai pengasuhan pertama anak, karena adanya sikap kepercayaan terhadap diri sendiri pada anak, maka nilai-nilai kejujuran mampu berkembang dalam kehidupannya. Jika anak ditempatkan dalam lingkungan keluarga yang tidak mendukung tumbuhnya rasa percaya dan sikap jujur dengan memperlihatkan kecurangan dan kebohongan pada anak, maka anak akan mengikuti sikap karakter buruk yang mereka dapatkan, hal ini memunculkan sikap kecurangan sejak dini yang akan melekat sampai dewasa.

Anak usia dini yang berkembang melihat penyimpangan - penyimpangan akan membentuk anggapan yang keliru terhadap nilai moral. Perihal ini lambat - laun dapat menyebabkan lunturnya nilai moral yang ada pada dirinya. Jarang sekali kita memandang orang berusia yang berbuat sikap korup, semacam menerobos traffight light. Apabila kanak- kanak kurang mampu mengidentifikasi Batasan antara penyimpangan serta kejujuran, mereka hendak berkembang jadi individu yang pragmatis serta mudah terpengaruh negatif. Nilai kejujuran sangat penting sebagi cikal bakal karakter individu yang memiliki moral yang baik, korupsi tidak serta tentang penggelapan uang, akan tetapi berkurangnya nilai kejujuran seperti berbohong pada orang tua dan menyontek saat ulangan bisa menjadi pembelajaran yang buruk terhadap nilai kejujuran kalau dibiarkan akan menjadi cikal bakal terjadinya korupsi.

Dengan memberikan penanaman nilai- nilai karakter yang baik sejak dini, maka anak akan mempunyai ketahanan atau benteng yang kuat untuk menghadapi pengaruh negatif yang muncul dari perkembangan teknologi dan pengaruh lingkungan sekitarnya. Tidak hanya itu Pembelajaran Anak Umur Dini( PAUD) mempunyai kedudukan berarti dalam tercapainya tujuan pembangunan berkepanjangan( Sustainable Development Goals- $S D G^{\prime}$ s). Cocok dengan tujuan yang ke 4 ialah membenarkan pembelajaran yang inklusif serta bermutu setara, pula menunjang peluang belajar seumur hidup untuk seluruh, maka dunia melalui PBB telah berkomitmen untuk meningkatkan kualitas pengembangan anak usia dini. Untuk mewujudkan tujuan tersebut, maka guru PAUD harus lebih kreatif dan inovatif dalam memberikan metode pembelajaran untuk membentuk karakter anak salah satunya dengan metode bercerita. Metode ini merupakan tindakan yang preventif untuk menanamkan nilai anti korupsi sejak dini dengan cara yang mudah dipahami dan pesan nilai yang disampaikan akan dilakukan oleh anak (Martin, 2014).

Dengan metode bercerita yang merupakan salah satu metode belajar yang disesuaikan dengan karakteristik anak mampu memberikan dan menanamkan nilai- nilai yang relevan karakter anti korupsi seperti sikap jujur, pantang menyerah, giat berusaha, tidak mencuri dan sebagainya. 
Metode bercerita dengan menggunakan beberapa sarana seperti boneka tangan, buku ataupun ekpresi yang membuat anak berimajinaasi tinggi, selain mampu membentuk karakter anak usia dini, juga dapat menjadi hiburan anak sehingga secara psikologis akan terbangun bonding antara guru/orang tua dengan anak, sehingga penyampaian nilai karakter antikorupsi akan tersampaikan., dengan demikian pendidikan antikorupsi akan tertanam pada anak usia dini.

\section{PEMBAHASAN}

\section{Korupsi}

Menurut (Nasir, 2006) korupsi yaitu perilaku yang rusak, memutar balik fakta, menggoyahkan, menyuap, orang yang menjadi target untuk disuap. Menurt (Azhar, 2003) yaitu berubah dari kondisi yang adil, benar dan jujur menjadi kondisi yang berlawanan. Dalam UU No. 31/1999 jo UU No. 20/2001 berisi tentang pidana korupsi meliputi :

1. Perbuatan melawan hukum yang merugikan negara untuk kepentingan pribadi.

2. Menyalahgunakan kewenangan untuk dengan jabatannya untuk kepentingan pribadi yang dapat merugikan keuangan negara, dengan pemerasan, gratifikasi dan menyuap pejabat negara

Dalam masyarakat Indonesia korupsi menjadi hal yang sudah biasa atau lumrah karena menurut oknum pelaku korupsi, tindakan mereka sudah sesuai dengan prosedur. Sehingga pelaku korupsi tidak merasa malu dan takut, bahkan sebaliknya bangga dengan hasil korupsinya yang diunggah melalui sosial media. Partai politik tidak lagi dijadikan wadah untuk memperjuangkan aspirasi rakyat, akan tetapi disalah gunakan oleh beberapa oknum politisi untuk kepentingan pribadinya sendiri. Padahal masalah korupsi sangat berbahaya karena mampu mengganggu stabilitas keamanan bangsa, negara dan masyarakat Indonesia.

Menurut (Ermansjah Djaja, 2010) masyarakat harus diingatkan tentang melonjaknya kasus perbuatan pidana korupsi akan membawa dampak yang berbahaya untuk bangsa Indonesia, selain merugikan bangsa dan laju perekonomian nasional tetapi juga pada stabilitas kehidupan bangsa dan negara.

Indeks persepsi korupsi (IPK) Indonesia pada 2020 tercatat sebesar 37 dari skala 0-100. Skor IPK tersebut turun 3 poin dibanding pada 2019 lalu. Perihal ini membuat Indonesia terletak di peringkat 5 Asia Tenggara, turun satu peringkat dibanding pada 2019. Posisi Indonesia disalip Timor Leste yang skor IPK-nya mengalami peningkatan 2 poin menjadi 40 pada 2020. Meskipun begitu, Indonesia merupakan negara yang mempunyai tingkat korupsi yang tinggi di Asia Tenggara.

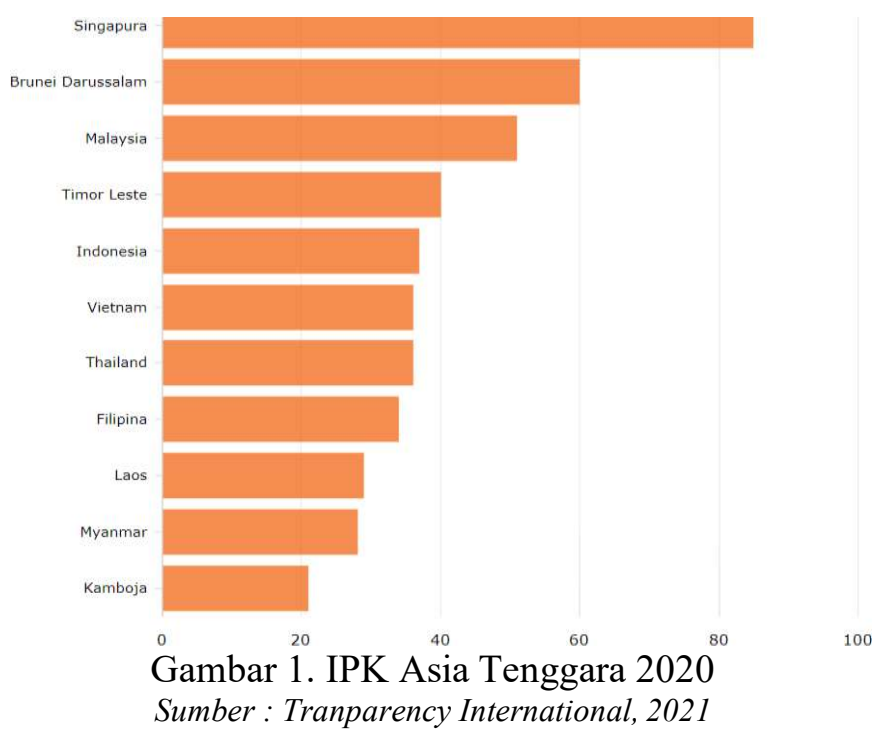

Dalam proses penindakan hukum yang tegas terhadap perbuatan pidana korupsi terdapat suatu fakta dilapangan adanya praktek penegakan secara tidak adil oleh penegak hukum. Fakta 
yang terjadi di lapangan masih terdapat kasus suap terhadap para penegak hukum yang dilakukan oleh koruptor sehingga mereka bebas dari hukuman atau mendapat hukuman yang ringan. Ketidak tegasan aparat hukum ini membuat kasus korupsi di Indonesia makin merebak dan mengakar dalam semua aspek kehidupan yang akan membahayakan eksistensi negara (Nyoman Serikat Putra Jaya, 2005). Korupsi dan kekuasaaan memiliki hubungan erat karena dengan kekuasaan penguasa mampu menyalahgunakan kekuasaan dan jabatannya demi kepentingan pribadinya (Romli Atmasasmita, 2004).

\section{Pendidikan Antikorupsi dengan Metode Bercerita}

Untuk mengatasi permasalahan korupsi melalui pendidikan anak usia dini, diperlukan suatu langkah yang relevan dalam pendidikan anti korupsi dengan menggunakan metode yang familiar pada anak usia dini. Menurut pasal UU Nomor 30/2002 tentang komisi Pemberantasan Korupsi Tindak Pidana Korupsi Pasal 13 C, yang berbunyi "Dalam melakukan tugas penangkalan sebagaimana diartikan dalam Pasal 6 huruf D, Komisi Pemberantasan Korupsi berwenang melakukan langkah atau usaha penangkalan menyelenggarakan program pembelajaran antikorupsi pada tiap jenjang pembelajaran.

Untuk mendukung program ini KPK sudah mengedukasi lewat banyak media yang mampu digunakan dalam bermacam aktivitas pendidikan antikorupsi. Pembelajaran yang menanamkan nilai antikorupsi sangatlah berarti selaku salah satu strategi dalam penangkalan masalah tindak pidana korupsi. Terdapat tiga strategi dalam penangkalan korupsi, ialah revisi sistem, reprensif, dan serta lewat bimbingan. Lewat bimbingan inilah kita selaku guru serta orang tua mengambil kedudukan, sebab perihal tersebut bukan cuma tugas KPK tetapi jadi tanggung jawab semua bangsa Indonesia.

Menurut (Agus, 2013) bahwa pembelajaran antikorupsi adalah usaha yang bertujuan untuk menciptakan proses pendidikan yang menunjang pada nilai-nilai antikorupsi. Dalam prosesnya, pendidikan antikorupsi diharapkan mampu membentuk karakter (afektif), dan kesadaran moral untuk menciptakan perlawanan terhadap penyimpangan tindakan korupsi.

Pembelajaran antikorupsi bertujuan agar memahamkan kepada anak didik tentang korupsi dan usaha untuk mencegahnya karena hal tersebut adalah tindakan yang merugikan kepentingan negara. Pada anak usia dini pendidikan antikorupsi merupakan upaya mencegah tindakan korupsi yang dimulai sejak anak usia dini. Mengingat subjek pendidikan antikorupsi adalah anak maka pendidikan antikorupsi harus menyesuaikan dengan dengan karakteristik anak, bersifat unik sesuai tingkat perkembangannya, salah satunya dengan teknik bercerita. Metode bercerita sangat familiar, dengan memberikan kisah fiktif yang terdapat nilai- nilai karakter didalamnya sangat bermanfaat bagi pendidikan karakter dan moral, mengingat subyeknya adalah anak usia dini maka pendidikan antikorupsi disesuaikan dengan usia anak. Menurut (Dhieni, 2005) bahwa cara bercerita disampaikan dan disajikan secara lisan dalam bentuk cerita dari guru kepada murid yang dikemas secara menarik. Anak usia dini yang berusia 0 sampai 6 tahun hanya mengetahui tindakan yang menyimpang menurut mereka seperti berbohong, tidak bertanggung jawab, tidak peduli terhadap sesama, serakah, belum memahami tentang tindakan korupsi. Membentuk kepribadian individu yang baik merupakan tujuan dari pengembangan karakter. Dengan karakter kepribadian yang baik akan mendorong anak untuk tumbuh dan memiliki komitmen untuk melakukan tindakan yang terbaik sesuai dengan tujuan hidupnya. Anak akan belajar menciptakan karakter baiknya ketika berinteraksi dengan teman sebaya di lingkungan sekolah, sehingga anak akan menunjukkan potensi mereka untuk mendapatkan sesuatu hal yang diharapkan (Baittstich, n.d.).

Metode bercerita merangsang anak untuk berimajinasi sesuai dengan tokoh dalam cerita. Dengan metode ini anak akan menerima nilai-nilai baik yang disampaikan oleh pencerita. Pencerita atau pendidik harus lebih kreatif menyampaikan cerita dengan alur dan media yang mudah diterima anak, bisa dengan menyanyi, cerita fabel dengan mimik wajah dan suara yang menyerupai tokoh fabel atau cerita komedi yang menghibur maupun tokoh perjuangan, hal ini dilakukan agar anak usia dini mudah memahami cerita yang disampaikan sehingga menjadi 
pembiasaan hidup sehari-hari. Cerita merupakan penggambaran tentang sesuatu secara verbal dengan gaya bahasa yang menarik. Cerita mampu dimanfaatkan untuk merangsang beberapa segi perkembangan anak, karena cerita dan kegiatan bercerita cenderung dekat dengan dunia anakanak, misalnya perkembangan bahasa, kognitif dan perkembangan social emosional. (Musfiroh, 2005), bermain sambil belajar agar berkembangnya moral dan social emosional, kegiatan motorik, dan perkembangan fisik adalah hal yang dekat dengan anak, dunia yang penuh imajinasi, dunia mengenal konsep-konsep baru.

Dalam metode bercerita memiliki kekuatan imajinasi yang kuat karena penjiwaan pencerita yang besar, hal ini dapat menciptakan kekuatan rasa ingin tahu anak yang tinggi . Dalam memberikan panduan dengan metode bercerita akan mampu menumbuhkan pendidikan antikorupsi melalui pemahaman nilai antikorupsi (moral kwoning), nilai pesan moral tentang gotong royong, keadilan, bersikap jujur, rasa peduli, tanggung jawab, sikap disiplin, keberanian, kegigihan, kesederhanaan, memahami nilai antikorupsi ( moral feeling ) nilai pesan moral tentang kejujuran, melakuakan pendidikan anti korupsi ( moral action ), nilai moral tentang keteladanan dan pembiasaan (Lickona, 1991).

\section{Bercerita yang Efektif}

Pendidik harus memperhatikan beberapa hal agar cerita yang disampaikan efektif dan pesan moralnya tersampaikan, diantaranya yaitu :

1. Pendidik harus memulai pembicaraan kepada anak dengan lebih hangat dan menyenangkan. Hal ini akan memudahkan pendidik untuk menceritakan apa saja pada anak, termasuk bercerita tentang nilai-nilai antikorupsi.

2. Pendidik harus banyak membaca buku agar bisa bercerita dengan baik dan menguasai cerita yang akan disampaikan. Daya fokus anak usia dini kurang lebih 15 menit sampai 20 menit, maksimalkan waktu efektif ini untuk mengemas cerita secara baik dan menarik.

3. Bercerita dengan dua arah, sambil menyanyi, tepuk dan tanya jawab akan membangun kedekatan dengan anak, anak akan merasa terhibur dan pesan moral yang dibawakan melalui cerita akan tersampaikan. Aktivitas bercerita mampu menggugah dan melibatkan beberapa emosi, mempengaruhi sikap perbuatan, dan menentukan pengambilan keputusan seseorang jika disampaikan dengan efektif. Oleh karena itu, cerita bisa dimanfaatkan sebagai cara dalam mengembangakan karakter kepada anak didik sejak dini. Bercerita merupakan kegiatan yang sangat potensial untuk merangsang perkembangan anak usia dini dan mampu menciptakan karakter dan juga melaksanakan pembelajaran pertama kepada anak-anak di dalam keluarga (Hidayati, n.d.).

\section{Manfaat Bercerita}

Metode bercerita banyak sekali manfaatnya untuk anak usia dini antara lain:

1. Meningkatkan pengetahuan tentang nilai moral dan agama.

2. Memberikan pengalaman-pengalaman baru yang akan menstimulus perkembangan kognitif, afektif dan psikomotorik anak.

3. Membangun blok bahasa melalui cerita yang sering didengar.

4. Meningktakan daya imajinasi dan daya konsentrasi anak.

5. Memberikan pengalaman baru untuk semangat dalam belajar dan berprestasi sesuai dengan pesan moral yang disampaikan oleh pencerita (Musfiroh, 2005).

\section{Strategi dalam bercerita}

Pendidik harus melaksanakan persiapan untuk menyampaikan cerita. Menurut (Gunawan, 2007) ada 3 hal penting yang harus disiapkan pendidik dalam bercerita, yaitu topik cerita, kemahiran menyampaiakan cerita, dan alat yang digunakan yang mendukung cerita.

1. Topik cerita, ialah pendidik harus sudah matang dalam memilih topik cerita yang akan disampaikan mulai dari pembukaan dan penutupan cerita. Dalam pembukaan dan penutupan pendidik harus lebih kreatif agar anak tertarik untuk menyimak, diawali dengan tepuk, nyayian,sulap, dramatisasi logat suara dan mimik wajah. Hal ini sangat penting agar pesan 
moral yang diselipkan dapat terkomunikasikan dengan baik.

2. Alur cerita yang dibuat harus runtut sesuai dengan urutan cerita sehingga anak akan dengan mudah untuk memahami cerita yang disampaikan.

3. Kemahiran bercerita, yaitu untuk anak usia dini seorang pencerita harus memiliki kemahiran dalam agar cerita mudah dipahami anak. Olah suara, gerakan tubuh, ekpresi mimik, dan cara menguasai suasana adalah ketrampilan yang harus dimiliki pencerita. Hal ini berkaitan dengan bercerita tanpa alat peraga.

4. Media peraga yang mendukung cerita, sangat diperlukan, untuk menarik perhatian anak. Contohnya : boneka tangan, buku, boneka dan gambar.

5. Mempersiapkan tempat yang bersih, nyaman dana man bagi anak.

6. Suara, intonasi, lafal pencerita, mimik dan gestur tubuh menjadi factor penting dalam keberhasilan dalam bercerita.

Dengan metode bercerita akan mampu mengenalkan anak tentang pendidikan antikorupsi. Secara sederhana anak akan mengetahui perilaku yang termasuk dalam tindakan korupsi sehingga mereka akan tahu pencegahannya melalui metode bercerita. Biasanya dalam metode bercerita ada sesi pembuka, isi dan sesi penutup. Pada sesi pembuka merupakan awal dari menarik perhatian anak ada melalui cerita yang akan disampaikan, biasanya diawali dengan tepuk, menyanyi dan lain sebagainya. Sedangkan pada bagian isi merupakan bagian penyampaian pesan moral antikorupsi, misal menyampaikan tentang karakter kejujuran yang sangat penting dalam kehidupan. Dalam metode bercerita ini bisa menggunakan media boneka tangan, buku cerita, dramatisasi penjiwaan ekspresi.. Pada bagian penutup adalah tahap kesimpulan dari cerita yang disampaikan. Libatkan anak untuk mengetahui pesan moral dalam cerita sehingga tujuan cerita akan tersampaikan dan dilakukan dalam kehidupan sehari-hari. Ketika pendidik sudah mampu menguasai anak dengan metode bercerita, maka nilai- nilai moral yang akan disampaikan seperti nilai anti korupsi, kejujuran, kedispilinan, tanggung jawab, kemandirian akan diterima anak dengan baik, disimpan dalam memori otak mereka dan diimplementasikan dalam kehidupan sehari-hari.

Setelah penyampaian cerita maka akan dilakukan evaluasi oleh guru ataupun orang tua, untuk mengetahui sejauh mana anak mampu menyerap cerita yang disampaikan sehingga mereka menerapkannya dalam perilaku dan karakter mereka. Pendidik harus senantiasa berkomunikasi aktif dengan orang tua tentang perkembangan anak didik, komunikasikan perkembangan karakter dan moral setelah bercerita dengan anak. Bisa juga dengan berkomunikasi dengan anak secara langsung melalui diskusi maupun pengamatan, ataupun berkomunikasi langsung dengan orang tua dengan bantuan layanan konseling sekolah. Nilai-nilai pendidikan antikorupsi dapat diterima oleh anak usia dini dengan cara melihat keteladan dan contoh dari lingkungan dan orang terdekat. Dengan melihat contoh pendidikan antikorupsi di sekitarnya anak akan melakukan pembiasaan antikorupsi dengan baik

Korupsi berhubungan dengan jabatan dan kewenangan karena dengan kewenangan tersebut penguasa dapat menyalahgunakan kewenangannya untuk kepentingan pribadi, keluarga dan teman-temannya. Dan hal ini terbentuk dari anak usia dini yang mendapatkan pengasuhan yang kurang baik oleh orang tua dan lingkungannya sehingga menjadi anak yang tidak berkarakter dan bermoral. Contoh real di masyarakat yaitu dengan masih banyaknya bentuk kecurangan dan ketidak jujuran dilingkungan mereka, seperti menyontek saat ujian, berprestasi dengan hasil curang dan lain sebagainya. Usaha pemberantasan pidana korupsi melalui penegakan hokum secara adil saat ini masih memerlukan perjuangan yang besar. Perlu adanya cara yang signifikan yang dilakukan pada saat masih dimasa keemasan mereka, karena dimasa ini anak akan mudah menyerap dan menerima apa yang dilihat, dirasa dan didengarkannya. 


\section{KESIMPULAN}

Dengan metode bercerita sangat tepat sebagai salah satu metode pembelajaran anak usia dini tentang antikorupsi, karena bercerita mampu memahamkan pada anak usia dini tentang pendidikan antikorupsi. Mengedukasi anak untuk memahami nilai antikorupsi, serta mengimplementasikan perilaku antikorupsi dalam kehidupan kesehariannya sesuai dengan 9 poin nilai anti korupsi yaitu sikap disiplin, sikap jujur, rasa tanggung jawab, kesederhanaan, kemandirian, kerja keras, bersikap adil, pemberani, dan kepedulian. Topik cerita yang disampaikan mampu mempengaruhi anak sehingga wajib memiliki pesan moral yang baik serta menarik yang akan mendukung anak untuk meneladani tokoh yang ada dalam cerita. Nilai moral yang ada dalam cerita hendak mempengaruhi imajinasi dan sikap anak sehingga mampu membentuk kepribadiannya dengan baik.

Agar kegiatan bercerita dapat sesuai dengan tujuan yang diharapkan perlu usaha secara sungguh-sungguh dan dilaksanakan secara rutin dan berkesinambungan, baik pada saat mempersiapkan ataupun pada waktu aktivitas penyampaian cerita itu berlangsung. Juga yang tidak kalah berartinya yaitu apa yang dilakukan sesudah bercerita, sehingga aktivitas penyampaian cerita tersebut tidak hanya berperan sebagai hiburan untuk anak, namun manfaatnya yang utama sebagai media pembelajaran juga harus berjalan dengan baik. Di samping itu, dibutuhkan kesadaran bahwa sesungguhnya aktivitas bercerita mampu digunakan sebagai perlambang cinta dan kasih-sayang guru terhadap muridnya, juga orang tua pada anak-anaknya. Dengan bercerita akan terbangun hubungan kedekatan pendidik dan anak didik, juga orang tua dananak-anaknya.

\section{REFERENSI}

Agus, W. (2013). Pendidikan Antikorupsi di Sekolah. Pustaka Pelajar.

Azhar, M. (2003). Pendidikan Antikorupsi, Partnership, Koalisis Antarumat Beragama untuk Antikorupsi. LP3 UMY.

Baittstich. (n.d.). History Teacher's Discussion Forum.

Dhieni, N. (2005). Metode Pengembangan Bahasa. Pusat Penerbitan Universitas Terbuka.

Ermansjah Djaja. (2010). Memberantas Korupsi Bersama KPK. Sinar Grafika.

Gunawan, T. (2007). Buku Panduan Teknik Bercerita. Penerbitan Sarana Bobo.

Hidayati, N. (n.d.). Manfaat Cerita bagi Kepribadian Anak.

Lickona, T. (1991). Educating for Character, How Our School Can Teach Respect and Responsibility. Bantam Books.

Makruf, A. J. (2012). Buku panduan Internalisasi Pendidikan Karakter di Sekolah. Pustaka Pelajar.

Martin. (2014). Dasar-Dasar Perencanaan Pendidikan. Raja Wali Pers.

Musfiroh, T. et al. (2005). Cerita dan Perkembangan Anak. Novila.

Nasir, R. (2006). Dialektika Islam dengan Problem Kontemporer. IAIN Press \& LKiS.

Nyoman Serikat Putra Jaya. (2005). Tindak Pidana Korupsi, Kolusi dan Nepotisme di Indonesia. Badan Penerbit Undip.

Romli Atmasasmita. (2004). Sekitar Masalah Korupsi, Aspek Nasional dan Aspek Internasional. Mandar Maju.

Rusman. (2015). Pembelajaran Tematik Terpadu, Teori Praktik dan Penilaian (Tiara (ed.)). Grafindo. 